\title{
Optimalisasi Perlindungan Saksi dan Korban Dalam Rangka Memantapkan Penegakan Hukum Di Indonesia
}

\author{
Syahrir Kuba ${ }^{1, *}$ \\ ${ }^{1}$ Fakultas Hukum; Universitas Bhayangkara Jakarta Raya; Jl. Perjuangan No.81, \\ RT.003/RW.002, Marga Mulya, Kec. Bekasi Utara, 02188955882; e-mail: \\ syahrir.kuba@dsn.ubharajaya.ac.id \\ * Korespondensi: e-mail: syahrir.kuba@dsn.ubharajaya.ac.id \\ Submitted: 04/01/2022; Revised: 18/01/2022; Accepted: 24/01/2022; Published: $31 / 01 / 2022$
}

\begin{abstract}
Crime is the shadow of civilization. Therefore, the crime will tend to increase in line with the increasingly rapid dynamics of community life. For this reason, it is necessary to take preventive measures or law enforcement intensively and consistently. One of the pieces of evidence that is required to be fulfilled in the law enforcement process is the testimony of a witness who testifies based on what he has heard, seen, and / or experienced himself. This law enforcement effort will not be successful if the community does not optimally participate in giving testimony. The role of witness and victims in supporting law enforcement has not been optimal due to various factors, including: Legislation regulating protection and victims in Indonesia which is still partial and well-known in various regulations and institutional structures are still limited at the central level, not yet at the regional level, including the legal awareness of the community to be witnesses, are still felt to be lacking. Efforts to increase protection and victims that need to be continuously evaluated and refined by relevant legislation, Development of protection and victim institutions (LPSK) up to the district level. For this reason, a strong commitment from the Government is needed to provide protection to witnesses and victims through strengthening the functions and roles of the Witness and Victim Protection Agency by fulfilling aspects of the legal structure and aspects of its legal substance in an effort to encourage changes in the legal culture of the community.
\end{abstract}

Keywords: Optimization, Protection, Victims, Witnesses

\begin{abstract}
Abstrak
Kejahatan memang pada hakekatnya merupakan bayang-bayang peradaban manusia. Oleh karenanya kejahatan itu akan cenderung mengalami peningkatan sejalan dengan perkembangan dinamika kehidupan masyarakat yang semakin pesat. Untuk itu perlu terus dilakukan upaya pencegahan maupun penegakan hukum secara intensif dan konsisten. Salah satu alat bukti yang dipersyaratkan harus dipenuhi dalam proses penegakan hukum adalah keterangan saksi yakni orang yang memberikan kesaksian berdasarkan apa yang ia dengar, ia lihat, dan/atau ia alami sendiri. Upaya penegakan hukum ini tidak akan berhasil dengan optimal manakala tidak melibatkan partisipasi masyarakat untuk secara aktif memberikan kesaksian. Belum optimalnya peran saksi dan korban dalam mendukung penegakan hukum selama ini disebabkan oleh berbagai faktor diantaranya: Perundang-undangan yang mengatur tentang perlindungan saksi dan korban di Indonesia yang masih bersifat parsial dan tersebar dalam berbagai peraturan serta secara struktural lembaganya masih terbatas di tingkat pusat, belum sepenuhnya sampai kedaerah, termasuk kesadaran hukum masyarakat untuk menjadi saksi masih dirasakan kurang. Upaya mengoptimalkan pelaksanaan perlindungan saksi dan korban perlu terus dilakukan melalui evaluasi dan penyempurnakan Perundang-undangan terkait, Pengembangan LPSK sampai ketingkat kabupaten. Di perlukan adanya komitmen yang kuat dari Pemerintah untuk memberikan perlindungan kepada saksi dan korban melalui pemantapan
\end{abstract}


fungsi dan peran LPSK dengan pemenuhan aspek struktur hukum dan aspek substansi hukumnya dalam upaya mendorong perubahan kultur hukum masyarakat.

Kata kunci: Optimalisasi, Perlindungan, Korban, Saksi

\section{Pendahuluan}

Perkembangan kejahatan dewasa ini semakin pesat, karena kejahatan memang pada hakekatnya merupakan bayang-bayang peradaban manusia (Crime is the shadow of civilization). Oleh karenanya kejahatan itu akan cenderung mengalami peningkatan sejalan dengan perkembangan dinamika kehidupan masyarakat yang semakin pesat akibat dari pengaruh globalisasi termasuk semakin cepatnya arus informasi masuk kedalam seluruh aspek kehidupan masyarakat, termasuk masyarakat Indonesia.

Untuk mengefektifkan pola penanggulangan kejahatan yang terjadi di negara Kesatuan Republik Indonesia, maka oleh Polri diklasifikasikan menjadi 4(empat) jenis kejahatan yaitu: (1) kejahatan Konvensional; (2) kejahatan Transnasional; (3) kejahatan terhadap kekayaan negara maupun; (4) kejahatan yang berimplikasi kontijensi (Hutasoit, 2004). Sedangkan oleh pakar hukum dan kriminologi di klasifikasikan menjadi 2(dua) jenis kejahatan yaitu: (1) kejahatan biasa (ordinary crimes) dan (2) kejahatan luar biasa (extra ordinary crimes).

Trend kejahatan di Indonesia, baik kejahatan biasa maupun kejahatan luar biasa saat ini cenderung semakin meningkat baik secara kuantitas maupun kualitas tentunya akan berimplikasi pada terganggunya ketenangan dan kedamaian hidup masyarakat, serta keamanan pada umumnya. Oleh karenanya menjadi tantangan bagi aparat pemerintah termasuk aparat penegak hukum dan aparat keamanan untuk menciptakan kedamaian dalam kehidupan masyarakat guna terciptanya masyarakat yang sejahtera (Tata Tentram Kerta Raharja), melalui upaya pencegahan maupun penegakan hukum secara intensif dan konsisten.

Upaya penegakan hukum yang dilakukan melalui proses peradilan pidana dimulai dari penyelidikan dan penyidikan serta penuntutan sampai sidang peradilan di pengadilan bertujuan menjatuhkan hukuman kepada pelaku melalui pengungkapan kebenaran material dan apa yang sesungguhnya telah terjadi serta mengapa itu terjadi, dengan menampilkan alat bukti dalam rangka membentuk keyakinan majelis hakim, guna memutuskan apakah terdakwa bersalah atau tidak dan apakah bisa dimintai pertanggungjawaban pidana.

Adapun alat bukti yang dipersyaratkan harus dipenuhi dalam proses peradilan pidana adalah keterangan saksi ( saksi yang meringankan [a de charge], saksi yang memberatkan [a charge], saksi ahli, saksi korban, saksi pelapor, saksi mahkota, saksi kunci, saksi fakta, saksi de auditu). Saksi menurut pasal 1 butir (1) Undang-Undang Republik Indonesia Nomor 31 Tahun 2014 tentang perubahan atas Undang-Undang Nomor. 13 Tahun 2006 tentang perlindungan saksi dan korban adalah orang yang dapat memberikan keterangan guna kepentingan penyelidikan, penyidikan, penuntutan, dan pemeriksaan di sidang pengadilan tentang suatu tindak pidana yang ia dengar sendiri, ia lihat sendiri, dan/atau ia alami sendiri (UU, 2014). Perbedaannya dengan rumusan KUHAP adalah dalam rumusan ini status saksi sudah dimulai 
ditahap penyelidikan, sedangkan dalam KUHAP status saksi dimulai dari tahap penyidikan (Muhadar, 2010). Perlindungan saksi dalam Undang-Undang Republik Indonesia Nomor 31 Tahun 2014 tentang perubahan atas Undang-Undang Nomor. 13 Tahun 2006 tentang perlindungan saksi dan korban ini memang lebih maju, karena berupaya mencoba memasukkan atau memperluas perlindungan terhadap orang-orang yang membantu dalam upaya penyelidikan pidana yang berstatus pelapor atau pengadu.

Upaya penegakan hukum ini tidak akan berhasil dengan optimal manakala tidak melibatkan partisipasi masyarakat (masyarakat tertentu, Korban, media, LSM, Whistleblower) untuk secara aktif memberikan kesaksian, informasi ataupun petunjuk dalam rangka mengungkapkan/ membuat terang suatu perkara, apalagi kejahatan yang terjadi saat ini sudah semakin kompleks, baik ditinjau dari modus operandi maupun motivasi pelaku/ tersangka/ terdakwa melakukan kejahatan yang sudah cenderung menjadikan kejahatan/ tindak pidana sebagai salah satu sumber kehidupan dalam membiayai dirinya, maupun kelompok guna mencapai target tertentu baik di bidang politik, maupun ideologi tertentu dalam meraih kekuasaan yang lebih besar, disamping pengaruh budaya hedonisme/mendewa-dewakan harta benda yang semakin melembaga dalam kehidupan masyarakat Indonesia (Arief, 2007).

Untuk menjadikan masyarakat sebagai saksi tentunya perlu mempertimbangkan berbagai aspek diantaranya: aspek fisik dan psykis/mental terutama terkait dengan jaminan rasa aman maupun dukungan finansial terutama masyarakat dari kelompok ekonomi lemah.

Oleh karena itu perlu diupayakan memberdayakan Saksi dan Korban dengan cara memberikan perlindungan yang intensif mulai dari proses penyelidikan dan penyidikan sampai kepada penggelaran persidangan di pengadilan dengan memperhatikan kemungkinan berbagai ancaman ataupun tekanan yang akan dihadapi baik secara mental maupun fisik agar saksi dan korban dapat memberikan keterangan dan informasi serta petunjuk yang relevan dengan kejahatan yang terjadi dengan bebas dan terbuka, sehingga pelaksanaan peradilan di pengadilan dapat berlangsung dengan objektif dan lancar, sehingga menghasilkan keputusan yang memberi rasa keadilan masyarakat, kepastian hukum dan memberikan kemanfaatan dalam upaya menegakkan supremasi hukum sesuai harapan masyarakat.

Hukum adalah seperangkat kaedah atau aturan baik tertulis ataupun tidak tertulis, yang tersusun dalam satu sistem yang menentukan apa yang boleh dan apa yang tidak boleh dilakukan oleh manusia sebagai warga masyarakat dalam kehidupan bermasyarakatnya, yang bersumber baik dari masyarakat sendiri maupun dari sumber lain yang diakui berlakunya oleh otoritas tertinggi (negara) dalam masyarakat itu, serta benar-benar diberlakukan secara nyata oleh warga masyarakat (sebagai satu keseluruhan, meskipun mungkin dilanggar oleh warga tertentu secara individual) dalam kehidupannya, dan jika dilanggar akan memberikan kewenangan bagi otoritas tertinggi untuk menjatuhkan sanksi yang bersifat eksternal bagi pelanggarnya (Ali, 1998).

Penegakan Hukum menurut Satjipto Rahardjo (2012), dengan berakhirnya pembuatan hukum, proses hukum baru menyelesaikan satu tahap saja dari suatu perjalanan panjang untuk 
mengatur masyarakat. Tahap pembuatan hukum masih harus disusul oleh pelaksanaannya secara konkrit dalam kehidupan masyarakat sehari-hari. Inilah yang disebut dengan penegakan hukum itu.

Saksi menurut pasal 1 butir (1) Undang-Undang Republik Indonesia No. 31 Tahun 2014 tentang Perubahan Atas Undang-undang nomor 13 Tahun 2006 tentang perlindungan saksi dan korban disebutkan bahwa saksi adalah orang yang dapat memberikan keterangan guna kepentingan penyelidikan, penyidikan, penuntutan, dan pemeriksaan di sidang pengadilan tentang suatu tindak pidana yang ia dengar sendiri, ia lihat sendiri, dan/atau ia alami sendiri.

Korban menurut Menurut pasal 1 butir (1) Undang-Undang Republik Indonesia No. 31 Tahun 2014 tentang Perubahan Atas Undang-undang nomor 13 Tahun 2006 tentang perlindungan saksi dan korban disebutkan bahwa korban adalah seseorang yang mengalami penderitaan fisik, mental, dan/atau kerugian ekonomi yang diakibatkan oleh suatu tindak pidana.

Perlindungan menurut pasal 1 butir (1) Undang-Undang Republik Indonesia No. 31 Tahun 2014 tentang Perubahan Atas Undang-undang nomor 13 Tahun 2006 tentang perlindungan saksi dan korban disebutkan bahwa Perlindungan adalah segala upaya pemenuhan hak dan pemberian bantuan untuk memberikan rasa aman kepada saksi dan/atau korban yang wajib dilaksanakan oleh LPSK atau lembaga lainnya sesuai dengan ketentuan undang-undang ini.

Lembaga Perlindungan saksi dan korban (LPSK) menurut pasal 1 butir (1) UndangUndang Republik Indonesia No. 31 Tahun 2014 tentang Perubahan Atas Undang-undang nomor 13 Tahun 2006 tentang perlindungan saksi dan korban disebutkan bahwa LPSK adalah lembaga yang bertugas dan berwenang untuk memberikan perlindungan dan hak-hak lain kepada Saksi dan/atau Korban sebagaimana diatur dalam undang-undang ini.

Optimalisasi menurut bahasa Indonesia Optimalisasi berarti pengoptimalan adalah proses, cara, perbuatan mengoptimalkan, yaitu menjadikan paling baik, menjadikan paling tinggi (Kamus Besar Bahasa Indonesia, 1999).

Kejahatan menurut Kamus bahasa Indonesia kejahatan adalah perilaku yang bertentangan dengan nilai-nilai dan norma-norma yang berlaku yang telah disahkan oleh hukum tertulis (Kamus Besar Bahasa Indonesia, 1999).

\section{Metode Penelitian}

Dalam rangka penelitian ini penulis menggunakan metode penelitian yuridis normatif dipadukan dengan yuridis empiris dengan pendekatan perundang-undangan (statute approach) dan pendekatan kasus (case approach) dengan menggunakan penalaran baik deduktif maupun induktif guna mendapatkan dan menemukan kebenaran obyektif. Pendekatan perundangundangan dilakukan untuk mengetahui konsistensi dan eksistensi undang-undang perlindungan saksi dan korban dalam penerapannya guna memenuhi tuntutan perlindungan hukum dan rasa 
keadilan masyarakat. Sedangkan pendekatan kasus dilakukan dengan menelaah berbagai keluhan masyarakat terkait perlindungan saksi dan korban dalam proses penegakan hukum.

\section{Hasil dan Pembahasan}

\subsection{Kondisi Pelaksanaan Perlindungan Saksi dan Korban Saat Ini}

Belum optimalnya peran saksi dan korban dalam mendukung penegakan hukum selama ini disebabkan oleh berbagai faktor diantaranya:

1. Perundang-undangan yang mengatur tentang perlindungan saksi dan korban termasuk Undang-undang perlindungan saksi dan korban dalam rangka penegakan hukum di Indonesia masih bersifat parsial dan tersebar dalam berbagai peraturan perundangundangan, sehingga hanya berlaku bagi kejahatan tertentu, seperti antara lain: (1) Tindak pidana korupsi; (2) Tindak pidana narkotika/psikotropika; (3), Tindak pidana Terorisme; (4) Tindak pidana yang mengakibatkan posisi saksi dan korban dihadapkan pada situasi yang sangat membahayakan jiwanya. Kriteria umum siapa dan bilamana dapat dikatakan adanya ancaman terhadap nyawa saksi dan korban masih belum ada kejelasan, sehingga perlindungan saksi dan korban belum bisa sepenuhnya diterapkan pada semua jenis kejahatan, padahal akibat yang ditimbulkan sama, berupa kerugian materil dan non materil dan belum sepenuhnya menempatkan saksi dan korban dalam posisi yang menentukan dalam proses peradilan pidana pada semua jenis kejahatan. Keterbatasan hak-hak yang diberikan kepada saksi dan korban masih sangat jauh jika dibandingkan dengan perlakuan terhadap tersangka /terdakwa, sebagaimana diatur dalam KUHAP, sedangkan perlindungan korban kejahatan kurang memadai sehingga kurang memberikan jaminan kepada saksi dan korban dalam memberikan keterangan, baik dalam proses penyelidikan dan penyidikan, maupun sebelum persidangan dilakukan, termasuk setelah mereka memberikan kesaksian. Semua itu akan menyebabkan masyarakat menjadi enggan untuk menjadi saksi, baik dalam proses penyelidikan/ penyidikan sampai pada proses peradilan pidana di persidangan di pengadilan. Disamping itu posisi korban digantikan oleh Jaksa/ penuntut umum menyebabkan korban termasuk keluarga korban tidak bisa lagi memiliki kontrol atas jalannya persidangan dan tidak pula dapat berperan dalam menentukan akhir dari proses peradilan pidana. Hal ini juga terjadi pada saksi lainnya, padahal kehadiran dan kesaksian mereka sangat menentukan dalam proses pemeriksaan di pengadilan, sehingga bila tidak diperankan akan menimbulkan masalah.

2. Lembaga perlindungan saksi dan korban yang dibentuk dengan undang-undang Nomor 13 tahun 2006 dan dirubah menjadi undang-undang Republik Indonesia Nomor 31 Tahun 2014 tentang perubahan atas Undang-Undang Nomor 13 Tahun 2006 tentang Perlindungan Saksi dan Korban secara struktural LPSK masih terbatas di tingkat pusat dan disebutkan LPSK mempunyai perwakilan didaerah sesuai dengan keperluan, dimana saat ini belum setiap provinsi memiliki perwakilan, sehingga belum sepenuhnya mampu melayani saksi dan korban dari seluruh wilayah Republik Indonesia, karena adanya 
keterbatasan secara struktural yang meliputi aspek organisasi dan hubungan tatakerja serta aspek sumber daya manusia dan materiil maupun anggaran, menyebabkan dalam pelaksanaannya masih dilakukan dengan methode selektifitas dan prioritas, akibatnya masih banyak kasus pidana yang belum sepenuhnya dapat dibuat terang/diungkapkan, walaupun termasuk kasus yang cukup besar terutama bila dilihat dari kerugian yang ditimbulkan maupun dampak yang ditimbulkan pada masyarakat yang berada di lingkup daerah yang jauh dari ibu kota Republik Indonesia.

3. Kesadaran hukum masyarakat yang menjadi korban kejahatan maupun masyarakat pada umumnya yang menjadi saksi masih dirasakan kurang. Hal ini disebabkan antara lain: (1) Takut dituntut balik sebagai pelaku penghinaan atau pencemaran nama baik; (2) Tidak mendapatkan perlindungan yang memadai; (3) Seringkali mendapatkan perlakuan kasar dan bahkan dibentak oleh penyidik apabila memberikan keterangan. Padahal menurut pasal 117 Ayat (1) KUHAP seorang saksi dalam memberi keterangan harus bebas dari tekanan dari siapapun dan dalam bentuk apapun (Hamzah, 2013), sehingga banyak saksi yang tidak mau menjadi saksi dalam proses peradilan pidana, karena takut diintimidasi atau mendapatkan tekanan dari penyidik; (4) Dalam memberikan keterangan didepan sidang pengadilan kurang mendapatkan perlindungan mengenai hak seorang saksi dengan baik, karena seorang saksi masih sering dipojokkan atau diintimidasi oleh pihak Jaksa Penuntut Umum (JPU) maupun Penasehat Hukum Terdakwa sehingga saksi tidak bebas memberikan keterangan sebagaimana mestinya; (5) Banyak kasus yang justru saksi yang dipersalahkan karena melakukan keterangan palsu atau sumpah palsu didepan pengadilan, sehingga takut menjadi saksi; (6) Khusus untuk perkara tertentu seperti terorisme, Tindak Pidana pencucian uang dan kasus pelanggaran HAM berat, Tindak Pidana korupsi sudah mendapat perlakuan atau perlindungan hukum seperti penyamaran identitas, sehingga saksi tidak merasa takut diintimidasi atau ditekan dari pihak yang dirugikan akibat keterangannya.

Dalam kaitan dengan kejahatan konvensional terutama kasus pencurian pemberatan, pencurian kekerasan/pencurian kendaraan bermotor dan pencurian ternak/hewan, masih ada keengganan dari korban untuk segera melaporkan masalah yang dialami kepada aparat penegak hukum, khususnya kejahatan konvensional yang terkait pencurian harta benda disebabkan karena antara lain : (1) Takut dibebani biaya oleh aparat penegak hukum; (2) Ada intimidasi dari oknum masyarakat yang diduga terkait sebagai pelaku yang berpura-pura mau/bisa membantu; (3) Takut waktunya banyak yang tersita apabila di jadikan saksi; (4) Takut dibebani biaya transport dari rumahnya ke kantor polisi/penegak hukum lainnya, karena sampai saat ini belum pernah ada penggantian biaya saksi yang telah datang memenuhi panggilan; (5) Terbatasnya pengetahuan masyarakat tentang peraturan hukum yang terkait masalah yang dihadapi. 
Disamping itu ada kecenderungan masyarakat untuk tutup mulut apabila diminta keterangan oleh petugas ditempat kejadian perkara (TKP) dan tidak mau menjadi saksi dengan alasan takut kepada pelaku, bahkan tidak mau memberi informasi kepada aparat kepolisian walaupun mereka tahu adanya tindak pidana karena takut dijadikan saksi di kantor polisi, sehingga mengakibatkan proses penyelidikan/penyidikan menjadi sangat lambat dan memakan waktu yang cukup lama/panjang (Kuba, 2009).

Faktor lain yang menyebabkan masyarakat disekitar tempat kejadian perkara (TKP) kurang kepedulian menolong korban antara lain (Kuba, 2009): (1) Karena merasa takut;(2) Merasa bukan kepentingannya;(3) Menganggap bahwa sudah ada pihak yang berwenang;(4) Tidak mau dirugikan dengan resiko menjadi saksi dan sebagainya. Semua ini menyebabkan informasi yang diperoleh oleh aparat kepolisian/penegak hukum menjadi sangat terbatas, sehingga penegakan hukum menjadi kurang efektif dan memakan waktu yang panjang/lama.

Secara umum harapan masyarakat dalam penegakan hukum antara lain:(1) Penegakan hukum dapat dilaksanakan secara jujur dan adil serta bertanggung jawab; (2) Polisi mampu menangkap pelaku dan mengembalikan barang yang dicuri, kemudian cukup diselesaikan secara kekeluargaan; (3) Polisi mampu menangkap pelaku dan mengembalikan barang yang dicuri, kemudian cukup diselesaikan dikantor polisi; (4) Polisi mampu menangkap pelaku dan mengembalikan barang yang dicuri, serta menahan pelaku, kemudian diproses sampai kepengadilan (Kuba, 2009).

Jadi sesungguhnya masyarakat yang menjadi korban kejahatan sangat menggantungkan harapannya kepada aparat penegak hukum khususnya Polri untuk dapat mengembalikan barang/harta benda mereka yang dicuri oleh pelaku dan menegakkan hukum secara konsisten dan konsekwen sesuai ketentuan hukum yang berlaku, walaupun masih beberapa diantaranya yang berharap tidak perlu diselesaikan sampai ketingkat pengadilan dengan beberapa pertimbangan yang cenderung bersifat subjektif.

Apabila harapan ini tidak dipenuhi oleh aparat penegak hukum, maka mereka akan menjadi kecewa terutama bila pelaku tidak dapat ditangkap dan diproses di pengadilan, sehingga berdampak terhadap turunnya kepercayaan kepada Polri/aparat penegak hukum. Kondisi ini merupakan tantangan bagi aparat penegak hukum dalam menangkap pelaku kejahatan dan mengembalikan barang/harta benda masyarakat yang dicuri. Sesungguhnya harapan utama masyarakat yang menjadi korban terutama pencurian adalah kembalinya harta benda mereka yang dicuri. Kondisi ini terjadi karena kemampuan perekonomian sebagian besar masyarakat kita yang menjadi korban kejahatan terutama pencurian termasuk dalam kategori golongan ekonomi menengah kebawah yang menempatkan harta benda sebagai suatu kebutuhan hidup yang masih bersifat primer.

Oleh karenanya untuk memenuhi harapan tersebut, maka aparat kepolisian dan aparat penegak hukum lainnya harus mampu mengoptimalkan penegakan hukum dengan lebih mengefektifkan proses penyelidikan dan penyidikan dengan melibatkan masyarakat sebagai 
saksi/sumber informasi, guna menjerat dan membawa para tersangka/terdakwa ke dalam peradilan pidana dipersidangan pengadilan melalui kejaksaan selaku penuntut umum.

\subsection{Pengaruh Saksi dan Korban dalam Mengefektifkan Proses Peradilan Pidana di Indonesia}

Seseorang dapat dihukum berdasarkan suatu pelanggaran pidana manakala terhadap orang tersebut terdapat unsur kesalahan (schuld) baik secara sengaja maupun karena kelalaian. Unsur kesalahan ini berkaitan erat dengan sifat melawan hukum yang menjadi unsur utama setiap tindak pidana. Selain itu juga harus dibuktikan unsur pertanggungjawaban (toerekeningsfaatbarheid) atas kesalahan tersebut Chairuddin Ismail (2009).

Dengan demikian dalam suatu penegakan hukum pidana harus dapat dibuktikan di muka persidangan tentang apakah perbuatan yang dipersoalkan memang memenuhi semua unsur tindak pidana yang didakwakan, dan kemudian apakah terdakwa terbukti secara sah dan meyakinkan telah melakukan kesalahan dan juga memenuhi syarat dapat dipertanggung jawabkan atas perbuatan tersebut. Untuk itulah dilakukan proses peradilan pidana (criminal justice process) mulai dari penyelidikan, penyidikan dan penuntutan serta peradilan dimuka sidang pengadilan.

Penyelidikan dan penyidikan yang dilakukan oleh aparat penegak hukum diawali dari suatu perkara yang gelap, apakah itu suatu tindak pidana, siapa pelakunya dan siapa yang dapat dijadikan saksi agar perkara tersebut menjadi terang. Sebagaimana diketahui bahwa hakekat penyidikan suatu tindak pidana (crime investigation) dalam upaya membuat terang suatu tindak pidana adalah pembuktian yang diperoleh melalui suatu proses yang menggunakan segi tiga pembuktian sebagai suatu pisau analisis, yang meliputi: Saksi (witness), Barang bukti (evidence) dan Pelaku (suspect), yang dikaitkan dengan Tempat Kejadian Perkara (TKP).

Kemudian dalam melakukan pembuktian itu, ada parameter hukum yang harus dipatuhi berdasarkan pasal 184 KUHAP yaitu harus berupa: (1) Keterangan saksi-saksi; (2) Keterangan Ahli; (3) Surat-surat/dokumen; (4) Petunjuk; dan (5) Keterangan terdakwa (Ismail, 2009). Jadi peranan saksi dan korban dalam hal ini sangat penting, karena sangat dibutuhkan dalam proses peradilan pidana mulai dari awal penyelidikan di Tempat Kejadian Perkara (TKP) dan penyidikan guna mendukung upaya pengungkapan/membuat terang tindak pidana, dan melakukan penyelidikan lebih lanjut, sebab untuk mendapatkan barang bukti atau bukti lainnya dan mengetahui /menangkap pelaku perlu didukung keterangan saksi atau petunjuk/informasi dari saksi, sampai ke peradilan di sidang pengadilan, oleh karenanya pelibatan masyarakat secara aktif sebagai saksi korban maupun saksi (yang mendengar, melihat dan mengalami tindak pidana) dalam upaya mengungkapkan/ membuat terang suatu perkara menjadi sangat penting, namun semua itu akan membutuhkan berbagai upaya untuk meyakinkan mereka agar mau menjadi saksi dalam proses penegakan hukum yg dimulai dari proses penyelidikan, penyidikan, dan penuntutan serta peradilan pada persidangan di pengadilan sampai penjatuhan hukuman. 
Peranan saksi dalam proses penyelidikan dan penyidikan sangat dibutuhkan untuk membuat terang perkara. Disamping itu peranan saksi dalam peradilan pidana melalui persidangan di pengadilan juga sangat penting karena seorang saksi dapat memberikan masukan dan memiliki kemampuan yang dapat mempengaruhi kecenderungan hakim dalam menentukan keputusan maupun dalam rangka membuat keputusan hakim sebagai bagian dari keberhasilan penegakan hukum dan sekaligus mengungkap kebenaran, termasuk berperan penting serta memiliki jasa yang sangat besar dalam upaya menjernihkan permasalahan terutama dalam forum persidangan di pengadilan. Semua peran yang dimainkan oleh saksi diharapkan dapat memberikan rasa keadilan, baik kepada terdakwa maupun korban dan masyarakat pada umumnya, disamping memberikan kepastian hukum kepada terdakwa dan kemanfaatan hukum bagi masyarakat pada umumnya.

Dengan memperhatikan hal tersebut diatas, jelas tergambar bahwa peranan saksi dan korban sangatlah penting. Oleh karena itu menjadi kewajiban negara melalui aparat penegak hukum terutama Lembaga Perlindungan Saksi dan Korban untuk memberikan perhatian khusus dalam wujud pemberian perlindungan dan pemberian hak-hak khusus kepada saksi dan korban, agar mereka dapat dan mau memberikan kesaksian mulai dari proses penyelidikan dan penyidikan sampai kepada proses sidang peradilan di muka pengadilan dengan bebas, lepas dan tanpa merasa ada tekanan maupun ancaman baik fisik ataupun psikis termasuk ancaman terhadap nyawa atau harta bendanya.

\subsection{Upaya Mengoptimalkan Pelaksanaan Perlindungan Saksi dan korban Guna Lebih Memantapkan Penegakan Hukum di Indonesia}

1. Perundang-undangan termasuk peraturan pemerintah maupun peraturan terkait lainnya atau petunjuk pelaksanaan (Juklak) yang mengatur tentang perlindungan saksi dan korban sebaiknya terus di evaluasi dan disempurnakan, sehingga menjadi lebih efektif dalam mendukung pelaksanaan proses peradilan pidana guna mengoptimalkan penegakan hukum, sesuai dengan dinamika perkembangan tuntutan dan harapan masyarakat (Tunggal, 2007). Hal tersebut perlu dilakukan dengan maksud agar saksi dan korban benar-benar dapat berperan aktif dalam memberikan semua keterangan yang diperlukan untuk mengungkap kebenaran tanpa ada rasa takut, mulai dari proses penyelidikan sampai pada persidangan di Pengadilan. Oleh karenanya posisi Lembaga Perlindungan Saksi dan Korban (LPSK) sebagai lembaga bersifat pasif yang hanya bisa bertindak apabila ada pihak yang menjadi korban atau saksi mengajukan permohonan untuk mendapat perlindungan Ke LPSK, perlu dievaluasi, sehingga kedepan LPSK lebih proaktif memberikan perlindungan kepada saksi dan korban mulai dari proses penyelidikan sampai ke proses peradilan disidang pengadilan, dengan bekerjasama instansi/aparat penegak hukum dan instansi terkait lainnya ditingkat pusat maupun daerah, termasuk dengan akademisi serta tetap menjaga harmonisasi, sehingga perlindungan saksi dan korban, menjadi optimal dalam mendukung efektivitas pelaksanaan proses peradilan guna lebih memantapkan penegakan hukum. 
2. Lembaga Perlindungan Saksi dan Korban (LPSK) sebaiknya berkordinasi dengan instansi terkait untuk membuat aturan/mekanisme yang berkaitan dengan teknis perlindungan diantaranya: (1) pemberian bantuan dan dukungan bagi saksi selama dalam proses persidangan di pengadilan; (2) Penyediaan tempat khusus bagi saksi dipengadilan selama mengikuti persidangan ; (3) Kesempatan berkonsultasi bagi para saksi secara bebas dan aman; (4) pemberian informasi tentang proses peradilan pidana terkait kejahatan yang menimpa korban. Disamping itu percepatan pemenuhan sarana dan prasarana pendukung seperti sarana mobilitas, alat komunikasi,perangkat teknologi informasi, ruang kerja dan ruang khusus/rumah aman ( safe house), termasuk ruang khusus pemeriksaan dalam proses penyidikan maupun ruang/tempat khusus di pengadilan perlu diprioritaskan, agar benar-benar menjamin kebebasan dan kerahasiaan saksi dalam memberikan keterangan guna mengungkap kebenaran.

3. Organisasi/Lembaga perlindungan saksi dan korban (LPSK) sebaiknya terus dikembangkan agar dapat lebih menyentuh kepada seluruh masyarakat yang terkait dengan proses peradilan pidana dalam rangka penegakan hukum diwilayah Negara Kesatuan Republik Indonesia mulai dari tingkat pusat sampai ketingkat kabupaten, minimal sampai ketingkat propinsi dengan tahapan skala prioritas pada daerah yang rawan kejahatan/kriminalitas, baik kejahatan konvensional menonjol maupun kejahatan tertentu atau kejahatan non konvensional yang sangat merugikan masyarakat maupun Negara..

4. Lembaga Perlindungan Saksi dan korban bekerjasama dengan aparat penegak hukum didukung Pemerintah pusat dan daerah sebaiknya terus melakukan upaya yang lebih konseptual untuk terus membangun komunikasi dengan komponen masyarakat yang terkait, baik melalui komunikasi langsung dengan tatap muka/sosialisasi/penyuluhan dengan melibatkan berbagai komponen masyarakat, maupun melalui media massa cetak dan media elektronik guna mendinamisir partisipasi masyarakat untuk melaporkan kejadian tindak pidana/kejahatan yang menimpa dirinya, disamping terus membimbing, mendorong, mengarahkan dan menggerakkan masyarakat agar senantiasa mau memberikan informasi/ dan berperan menjadi saksi dalam rangka mengungkapkan suatu kejahatan/ membuat terang suatu tindak pidana.

5. Hubungan dan tata cara kerja (HTCK) internal dan eksternal Lembaga Perlindungan Saksi dan Korban sebaiknya disusun/disempurnakan mulai dari tingkat pusat sampai ketingkat propinsi/Daerah, dengan melibatkan instansi terkait, sehingga diharapkan sinerji dan keterpaduan dalam melaksanakan rangkaian proses peradilan pidana akan semakin efektif, yang diharapkan pada akhirnya dapat mendorong upaya memantapkan penegakan hukum di wilayah Republik Indonesia.

6. Program perkuatan Sumber Daya Manusia yang bertugas pada Lembaga Perlindungan Saksi dan Korban perlu terus dilakukan dalam rangka peningkatan kemampuan sumber daya manusia baik secara kuantitas dan kualitas guna meningkatkan profesionalisme mereka dalam memberikan perlindungan terhadap saksi dan korban, sehingga dapat 
berkontribusi untuk mendukung upaya mengefektifkan peradilan pidana yang pada akhirnya diharapkan pelaksanaan penegakan hukum akan menjadi semakin optimal, terutama pada kejahatan tertentu yang sangat merugikan masyarakat maupun Negara.

7. Sebaiknya terus dibangun komunikasi dan koordinasi serta kerjasama antara Lembaga Perlindungan Saksi dan Korban (LPSK), aparat penegak hukum (Kepolisian dan Kejaksaan) maupun dengan aparat Pemerintah ditingkat pusat dan Daerah, termasuk akademisi dalam rangka mengkaji bersama secara tuntas hal-hal yang terkait dengan masalah hukum maupun non hukum dalam rangka memberdayakan pranata perlindungan saksi dan korban, terutama ditujukan terhadap perkara yang pembuktiannya hanya bergantung pada saksi dan korban. sehingga tetap dapat diciptakan harmonisasi dalam pelaksanaan tugas penegak hukum.

8. Mendorong Lembaga Perlindungan Saksi dan Korban agar tidak hanya berperan melindungi saksi dan korban dari aspek fisik dan psikis saja, tetapi sebaiknya ikut berperan lebih aktif dalam upaya perlindungan terhadap hak korban untuk memperoleh kembali hak (harta benda) miliknya yang hilang akibat kejahatan yang menimpanya, dengan cara bekerjasama aparat penegak hukum, dan bila perlu diikuti dengan membuat kesepakatan bersama terkait dengan mekanisme pengembalian harta benda/barang/uang korban yang telah ditemukan oleh aparat penegak hukum, baik yang ada pada Polri, kejaksaan dan pengadilan maupun aparat penegak hukum lainnya.

9. Sebaiknya Lembaga Perlindungan Saksi dan Korban senantiasa mengkoordinasikan dengan aparat penegak hukum guna dilakukan pengkajian dan dicarikan solusi yang terbaik terkait dengan penjatuhan sanksi pidana yang sering didakwakan kepada mereka yang menjadi saksi dan korban, khususnya terkait dengan pasal penghinaan atau pencemaran nama baik dan bagaimana seharusnya mereka diperlakukan sebagai saksi dan korban terkait dengan perannya dalam mengungkap suatu kejahatan, dan bila perlu dituangkan dalam bentuk kesepakatan bersama ataupun bila memungkinkan dituangkan dalam bentuk peraturan sehingga tidak membuat masyarakat takut menjadi saksi dalam proses peradilan.

\section{Kesimpulan}

Berdasarkan Undang-Undang Republik Indonesia Nomor 31 Tahun 2014 tentang perubahan atas Undang-Undang Nomor. 13 Tahun 2006 tentang perlindungan saksi dan korban dan secara struktural masih terbatas ditingkat pusat dan beberapa provinsi serta hanya melayani perlindungan terhadap masyarakat yang terkait pada kasus tertentu disamping itu masih lebih bersifat pasif menunggu permintaan dari saksi maupun korban. Kemudian kesadaran hukum masyarakat untuk menjadi saksi mulai dari penyelidikan sampai persidangan masih rendah, akibatnya proses peradilan pidana menjadi kurang efektif, sehingga penegakan hukum menjadi kurang optimal. Pelaksanaan proses peradilan pidana mulai dari penyelidikan sampai dengan sidang peradilan di pengadilan terhadap kejahatan konvensional maupun non 
konvensional belum dapat berjalan dengan efektif karena saksi dan korban belum sepenuhnya dapat berperan sesuai sistem pembuktian. Mereka yang diharapkan mau menjadi saksi masih sering dihadapkan dengan berbagai kendala, berupa ancaman fisik dan psikis maupun pemenuhan hak-hak mereka sebagai seorang saksi, menyebabkan penegakan hukum menjadi kurang efektif. Pelaksanaan perlindungan saksi dan korban akan menjadi optimal bila didukung oleh perundang-undangan, disamping memantapkan sumber daya manusia yang bertugas di Lembaga Perlindungan Saksi dan Korban dan mencukupi sarana dan prasarana pendukung tugas, disamping mengambil langkah-langkah peningkatan kesadaran hukum masyarakat, terus dilakukan secara konsisten dan berlanjut, agar pelaksanaan penegakan hukum akan menjadi lebih optimal.

\section{Daftar Pustaka}

Ali, A. (1998). Menjelajahi Kajian Empiris Terhadap Hukum. Retrieved from PT Yarsif Watampone

Arief, B. N. (2007). Masalah Penegakan Hukum dan Kebijakan Hukum Pidana dalam Penanggulangan Kejahatan. Jakarta: Kencana Prena Media Group.

Hamzah, A. (2013). KUHP \& KUHAP (Revisi). Jakarta: Rineka Cipta.

Hutasoit, T. (2004). Menjadi Polisi Yang Dipercaya Rakyat (Tahapan Perjalanan Reformasi Polri). Jakarta: Markas Besar Kepolisian Negara Republik Indonesia.

Ismail, C. (2009). Kapital Selekta Penegakan Hukum Tindak Pidana Tertentu (Revisi). Jakarta: PTIK Press.

Kamus Besar Bahasa Indonesia. (1999). Jakarta: Balai Pustaka.

Kuba, S. (2009). Optimalisasi Penegakan Hukum Terhadap Kejahatan Konvensional Oleh Kepolisian Negara Republik Indonesia Daerah Sulawesi Selatan. Universitas Hasanuddin Makassar.

Muhadar. (2010). Perlindungan Saksi dan Korban dalam Sistem Peradilan Pidana. Surabaya: PMN.

Rahardjo, S. (2012). IImu Hukum. Bandung: PT Citra Aditya Bakti.

Tunggal, H. S. (2007). Undang-Undang Perlindungan Saksi dan Korban (Undang-Undang Nomor 13 tahun 2006). Jakarta: Harvarindo.

UU. Perubahan atas Undang-Undang Nomor 13 tahun 2006 mengenai perlindungan saksi dan korban., Pub. L. No. 31(2014). 